\title{
Semptomatik Hipokalsemi ve Nütrisyonel Rikets Nedenli Hastane Başvuruları: Göçmen Suriye'li Süt Çocuklarının Predominansı
}

\section{Hospital Admissions due to Symptomatic Hypocalcemia and Nutritional Rickets: Predominance of Immigrant Syrian Infants}

\author{
Melek Yıldız ${ }^{1,2}$ (D), Suna Kılınç ${ }^{3}$ (D) \\ ${ }^{1}$ Sağılık Bilimleri Üniversitesi, İstanbul Kanuni Sultan Süleyman Eğitim ve Araştırma Hastanesi, Çocuk Endokrinoloji Bölümü, İstanbul, Türkiye \\ 2istanbul Üniversitesi İstanbul Tıp Fakültesi, Çocuk Endokrinoloji Bilim Dalı, İstanbul, Türkiye \\ ${ }^{3}$ Sağılık Bilimleri Üniversitesi, İstanbul Bağcılar Eğitim ve Araştırma Hastanesi, Çocuk Endokrinoloji Bölümü, İstanbul, Türkiye
}

ORCID ID: M.Y. 0000-0002-6603-2983; S.K. 0000-0002-0760-2640

Attf/Citation: Yildiz M, Kilinc S. Semptomatik hipokalsemi ve nütrisyonel rikets nedenli hastane başvuruları: Göçmen Suriye'li süt çocuklarının predominansı. Çocuk Dergisi - Journal of Child 2020;20(2):53-58. https://doi.org/10.26650/jchild.2020.2.777695

öz

Amaç: Nütrisyonel rikets, büyüme çağındaki çocuklarda $D$ vitamini ve kalsiyum eksikliğine bağlı olarak gelişen epifizyal kıkırdağın defektif mineralizasyonudur. Nütrisyonel riketsin önlenmesi için D vitamini profilaksisi ülkemizde süt çocukluğu döneminde rutin olarak uygulanmaktadır. Ancak halen semptomatik hipokalsemi ve $\mathrm{D}$ vitamini eksikliği nedeniyle hastane başvurularının olması dikkat çekicidir. Çalışmamızda bu olguların özelliklerinin ortaya konulması amaçlanmıştır.

Gereç ve Yöntem: Ocak 2018-Mayıs 2018 tarihleri arasında nütrisyonel rikets tanısı ile yatırılarak izlenmiş olan 28 hastanın ( 9 kız, 19 erkek) verisi retrospektif olarak incelendi. Olguların başvuru anındaki antropometrik ve laboratuvar özellikleri kaydedildi.

Bulgular: Olguların ortanca başvuru yaşı 8,8 (1-35) ay idi. Olguların $\% 67,9^{\prime}$ u Suriye göçmeni idi. Hastaların $\% 57,1^{\prime} i$ hiç D vitamini profilaksisi almamış, \%42,9'u ise düzensiz almıştı. Başvuru yakınması olguların $\% 50$ 'sinde konvülsiyon geçirme, \%28,6'sında rikets bulguları iken $\% 21,4$ 'ünde ise ateş, enfeksiyon vb. nedenlerden dolayı hastaneye başvuran hastalarda rastlantısal olarak hipokalsemi tespit edilmiş olması idi. illk başvuruda ortanca kalsiyum $6,6 \mathrm{mg} / \mathrm{dL}$; iyonize kalsiyum $0,85 \mathrm{mmol} / \mathrm{L}$; fosfor $3,5 \mathrm{mg} / \mathrm{dL}$; alkalen fosfataz $787 \mathrm{U} / \mathrm{L}$; parathormon $241 \mathrm{pg} / \mathrm{mL}$ ve 25 -hidroksi vitamin D 3,4 ng/mL saptanmıştı. Olguların \%60,7'sinde hipofosfatemi, \%3,6'sında hiperfosfatemi mevcuttu. Tüm olgular hastanede yatıılarak tedavi edilmiş ve $D$ vitamini eksikliğine bağlı nütrisyonel rikets tanısı almıştı.

Sonuç: Ülkemizde D vitamini profilaksisine rağmen halen nütrisyonel rikets görülebilmekte ve kış-ilkbahar aylarında hipokalsemik konvülsiyon nedeniyle hastane başvurularına yol açabilmektedir. Özellikle göçmen Suriyeli süt çocuklarında D vitamini destek programına uyumun artırıması nütrisyonel riketsin önlenmesi açısından önemlidir.
ABSTRACT

Objective: Nutritional rickets is a disorder of defective mineralization of growth plate in growing children due to vitamin $\mathrm{D}$ and calcium deficiency. In our country, vitamin $D$ is routinely used during infancy to prevent nutritional rickets. However, it is noteworthy that there are still hospital admissions due to symptomatic hypocalcemia and vitamin $D$ deficiency. Our study aimed to reveal the features of these cases.

Material and Method: Data of 28 patients ( 9 girls, 19 boys) hospitalized due to nutritional rickets between January 2018 and May 2018 were analyzed retrospectively. Anthropometric and laboratory features of the patients were recorded.

Results: The median age of admission was 8.8 (1-35) months. Most of the patients $(67.9 \%)$ were immigrants from Syria. $57.1 \%$ of patients didn't receive any vitamin D prophylaxis, while $42.9 \%$ received irregularly. Majority of patients (50\%) were admitted due to convulsion, while $28.6 \%$ with signs of rickets and $21.4 \%$ with incidental hypocalcemia. At the time of admission, median calcium was $6.6 \mathrm{mg} / \mathrm{dL}$; ionized calcium 0.85 $\mathrm{mmol} / \mathrm{L}$; phosphorus $3.5 \mathrm{mg} / \mathrm{dL}$; alkaline phosphatase $787 \mathrm{U} / \mathrm{L}$; parathormone $241 \mathrm{pg} / \mathrm{mL}$ and 25-hydroxyvitamin D was $3.4 \mathrm{ng} / \mathrm{mL}$. Hypophosphatemia was detected in $60.7 \%$ of the patients, while $3.6 \%$ had hyperphosphatemia. All patients were hospitalized and diagnosed as nutritional rickets due to vitamin $D$ deficiency.

Conclusion: Despite vitamin D prophylaxis in our country, nutritional rickets can still be seen and lead to hospital admission due to hypocalcemic convulsions in winter and spring. Increasing the compliance with vitamin D support program especially for immigrant Syrian infants is essential for the prevention of nutritional rickets.

Keywords: Nutritional rickets, vitamin D, hypocalcemia, immigrant children

Anahtar Kelimeler: Nütrisyonel rikets, D vitamini, hipokalsemi, göçmen çocuklar 


\section{GíRiş}

Rikets, büyüme çağındaki çocuklarda D vitamini ve kalsiyum eksikliğine bağı gelişen metabolik bir kemik hastalığıdır. Klasik olarak bilinen rikets evrelerine göre klinik ve biyokimyasal bulgular ortaya çıkar. D vitamini yetersizliğinin başlangıcı ile rikets gelişimine kadar olan süre her çocuğa göre değişkenlik gösterir (1). D vitamini vücutta, parathormon (PTH) ve kalsitonin ile birlikte kemik, böbrek ve barsak arasındaki kalsiyum fosfor dengesini sağlamaktadır. Eksikliğinde, serum ve hücre içi kalsiyum-fosfor düzeyindeki değişikliklere bağıı olarak, büyüme plağı gelişimi bozulur; yetersiz mineralizasyon ve osteotrofik hormonların etkisiyle kemik sağlamlığı azalır ve klinik bulgular ortaya çıkar.

Riketsin en sık nedeni D vitamini eksikliğine bağlı ortaya çıkan nütrisyonel riketstir (2). Vakaların çoğunluğu D vitamini profilaksisi almayan, uzun süre anne sütü alan, annelerinde D vitamini eksikliği olan, kış aylarında doğan ve güneşe çıkarılmayan bebeklerdir $(3,4)$. Nütrisyonel rikets, büyüyen organizmanın hastalığı olup, sıklıkla 0-3 yaş arası süt çocuklarında gözlenmektedir. Vakaların bir kısmı silik klinik bulgularla başvururken, bir kısmında semptomatik hipokalsemi görülebilmektedir. Hipokalsemiye bağı nöromusküler uyarılma sonucunda tetani, kas spazmları, laringeal spazm ve jeneralize nöbetler görülebilir (5). Rikets vakalarının erken bebeklik döneminde daha sık hipokalsemi ile başvurduğu bildirilmiştir (6).

Gelişmiş ülkelerde çok daha az görülen nütrisyonel rikets Türkiye gibi gelişmekte olan ülkelerde hala önemini koruyan bir halk sağlığı sorunudur. İnsidansı hem ülkelere hem de bölgelere göre farklılık göstermektedir. Ülkemizde nütrisyonel rikets insidansı farklı bölgelerde \%1-6 arasında bildirilmiştir (7-9). 2013 yılında yayınlanan bir çalışmada dünyada rikets insidansının giderek arttı̆ı belirtilmiştir (10). Son yıllarda nütrisyonel riketsin önlenmesinde D vitamini profilaksisinin önemi anlaşımış ve birçok ülkede uygulanmaya başlanmıştır (4). Türkiye'de 2005 yılından itibaren koruyucu hekimlik kapsamında 0-1 yaş arası tüm çocuklara 400 IU/gün D vitamini verilmektedir (11). Bu durum nütrisyonel riketsin sıklığını ve şiddetini azaltmıştır. Ancak kırsal kesim ve gecekondu bölgelerinde hala önemli bir halk sağlığı sorunu olmaya devam etmektedir. Diğer yandan ülkemizdeki göçmen çocuklar kötü yaşam koşulları, beslenme sorunları ve sağlık hizmetlerine erişim eksikliği nedeniyle nütrisyonel rikets açısından risk altındadır $(12,13)$. Suriye'de 2011 yılından itibaren devam eden iç savaşın etkisiyle başta Türkiye'de olmak üzere çeşitli ülkelerde göçmen krizi ortaya çıkmıştır. Göç İdaresi Genel Müdürlüğü'nden elde edilen son rakamlara göre, ülkemizde geçici koruma statüsü kazanmış 3,6 milyon Suriyeli göçmen yaşamakta ve bu kişilerin çoğu kamplarda değil, Türkiye genelinde dağılmış olarak bulunmaktadır (14). Ülkemizde Suriyeli göçmen çocukları koruyucu hekimlik kapsamında güvence altına alınmıştır.

Bu yazı, literatürdeki son bilgiler ve ülkemizdeki veriler ışı̆̆ında D vitamini eksikliği ve nütrisyonel rikets sorununa dikkat çekmektedir. Çalışmamızda İstanbul'da iki farklı merkez tarafindan tanı konulan semptomatik hipokalsemi ve nütrisyonel rikets olgularının özellikleri sunularak, Suriye'deki iç savaştan kaçıp ülkemize gelen göçmen süt çocuklarının bu olgular arasındaki yeri ve bu göçmen çocuklarının göç ettikleri yerlerde yaşadıkları bu sağlık sorununa dikkat çekilmesi amaçlanmıştır.

\section{GEREÇ VE YÖNTEM}

Çalışmamızda İstanbul Kanuni Sultan Süleyman Eğitim ve Araştrrma Hastanesi ve Bağcılar Eğitim ve Araştırma Hastanesi çocuk kliniklerinde Ocak 2018-Mayıs 2018 tarihleri arasında hipokalsemi ve nütrisyonel rikets tanıları ile yatarak izlenmiş olan, 0-3 yaş arası 28 hastanın verisi hasta dosyaları ve hasta kayıt formlarından retrospektif olarak incelendi. Çalışma öncesi Etik Kurul Onayı alındı (No: 2018.11.2.03.100.r1.111). Olguların uyruğu, başvuru yaşı, başvuru şikâyeti, cinsiyeti, antropometrik ölçümleri, D vitamini profilaksisi alıp almadığı, beslenme şekli ve eşlik eden hastalık varlığı kaydedildi. Başvuru sırasında ölçülen kalsiyum, fosfor, alkalen fosfataz (ALP), magnezyum, albümin, iyonize kalsiyum, PTH ve 25-hidroksi vitamin D (25-OHD) düzeyleri kaydedildi. Hastalardan annesi tetkik edilenlerin ayrıca anne serum kalsiyum, fosfor, ALP, PTH ve 25-OHD düzeyleri kaydedildi.

Serum kalsiyum düzeyinin $8,5 \mathrm{mg} / \mathrm{dl}$ 'nin altnnda olması hipokalsemi olarak kabul edildi. $25-$ OHD düzeyi $<5 \mathrm{ng} / \mathrm{ml}$ ise ağır, $5-10$ $\mathrm{ng} / \mathrm{ml}$ ise orta, $10-15 \mathrm{ng} / \mathrm{ml}$ ise hafif D vitamini eksikliği; $15-20$ $\mathrm{ng} / \mathrm{ml}$ ise $D$ vitamini yetersizliği kabul edildi. Nütrisyonel rikets tanısı hipokalsemi yanında riketse özgü radyolojik bulgular ve ALP yüksekliği veya 25-OHD düşüklüğünden birisinin olmasına göre konuldu. Hafif hipokalsemi saptanan, hipoparatiroidi tanısı alan, hastaneye yatış endikasyonu olmayan, nütrisyonel rikets tanısı olmayan ya da nütrisyonel rikets olup 3 yaşından büyük olan hastalar çalışmaya dâhil edilmedi.

\section{İstatistiksel Değerlendirme}

Bu çalışmada elde edilen veriler SPSS 23.0 programı ile analiz edildi. Normal dağılım gösteren değişkenlerin analizinde parametrik yöntem, normal dağılım göstermeyen değişkenliklerin analizinde nonparametrik yöntem uygulandı. Kökenine göre gruplandırılan hastaların laboratuvar değerleri Mann-Whitney U testi ile karşılaştırıldı. Hastaların başvuru yaşı ve laboratuvar parametreleri arasındaki korelasyon Pearson testi ile incelendi. İstatistiksel karşılaştırmalarda $p<0,05$ değeri istatistiksel olarak anlamlı kabul edildi.

\section{BULGULAR}

Çalışmaya 19'u Suriye kökenli olan, 9 kız ve 19 erkek bebekten oluşan, toplam 28 hasta alındı. Yaş ortalaması 8,8 (1-35) aydı. Ortalama doğum ağırlığı 3297£639 gr olan hastaların tamamı miadında doğmuştu. Bir hasta düşük doğum ağırlığı (2000gr) ile, 1 hasta da makrozomik (4000 gr) doğmuştu. Çalışmaya dâhil edilen hastaların klinik ve sosyodemografik özellikleri Tablo 1'de gösterilmiştir.

Suriye kökenli 7 aylık bir hasta yaklaşık 3 aydır yalnızca pastörize inek sütü ile beslenmekteydi. Ayrıca 3 hastada daha tamamlayıcı beslenmeye uygun geçilmemişti ve hastalar yaklaşık 8 aylık oluncaya kadar sadece anne sütü almışlardı. Diğer hastalar ilk 4-6 ay sadece anne sütü ile beslenmiş, sonrasında ek gıdalar ile tamamlayıcı beslenmeye geçilmişti. Hastaların \%57,1'i hiç D vitamini profilaksisi almamış, \%42,9'u ise düzensiz kullanmışt. Hastaların kökenine göre D vitamini kullanımı açısından anlamlı bir fark yoktu. 
Tablo 1: Nütrisyonel riketsli olguların klinik ve sosyodemografik özellikleri

\begin{tabular}{lc}
\hline & $\mathbf{n}(\%)$ \\
\hline Tüm olgular & 28 \\
Cinsiyet & $9(32,1)$ \\
$\quad$ Kız & $19(67,9)$ \\
$\quad$ Erkek & \\
Uyruk & $9(32,1)$ \\
$\quad$ Türkiye & $19(67,9)$ \\
$\quad$ Suriye & $8,8(1-35)$ \\
Başvuru yaşı (ay) (ortanca (alt-üst sınır)) & \\
Başvuru yakınması & $14(50,0)$ \\
$\quad$ Konvülsiyon & $6(21,4)$ \\
$\quad$ Rastlantısal hipokalsemi & $8(28,6)$ \\
$\quad$ Rikets bulguları & \\
D vitamini profilaksisi & $16(42,9)$ \\
Düzensiz kullanıyor & $-0,5(-1,7-2,0)$ \\
Kullanmıyor & $-0,3(-2,31-1,17)$ \\
\hline Bğırlık SDS (ortanca (alt-üst sınır)) &
\end{tabular}

SDS: standart deviyasyon skoru

Başvuru şikâyetleri açısından incelendiğinde hastaların \%50'si (14 hasta) nöbet geçirme nedeniyle acil servise başvurmuştu. 6 hasta ateş, akut gastroenterit, akut bronşiolit gibi nedenlerle tetkik edilirken rastlantısal olarak hipokalsemi saptanmışt. Sekiz hasta ise bacaklarda eğrilik ve yürümede gecikme gibi rikets bulguları nedeniyle tetkik edilirken yatış gerektiren ağır hipokalsemi saptanmışt. Boy kısalığı saptanan 20 aylık bir hasta haricinde (boy SDS: -2,31) hastaların büyüme ve gelişmesi normaldi. Hastaların el bilek grafisinde radius ve ulna distal metafizinde düzensizlik ve çanaklaşma bulunmaktaydı. Eşlik eden kronik hastalık veya ilaç kullanım öyküsü olan hasta yoktu. Tüm olgular Ocak-Mayıs döneminde, kış ve ilkbahar aylarında hastanede yatırılarak tedavi edilmişti.
Laboratuvar değerlendirmesinde hastaların tamamında serum kalsiyum ve iyonize kalsiyum düzeyleri düşük, hipokalsemi mevcuttu. Serum albümin, magnezyum düzeyleri ve kan gazı normaldi. On yedi $(\% 60,7)$ hastada hipofosfatemi, $1(\% 3,6)$ hastada ise hiperfosfatemi saptandı. Hiperfosfatemi saptanan 1,5 aylık hastanın ağır D vitamini eksikliği mevcuttu. PTH normal saptanan 8 aylık bir hast dışında tüm olgularda ALP ve PTH düzeyleri yüksekti. Yirmi dört $(\% 85,7)$ hastada ağır, $4(\% 14,3)$ hastada orta düzeyde D vitamini eksikliği mevcuttu. Türkiye kökenli hastaların serum kalsiyum düzeyleri Suriye kökenli hastalara göre anlamlı derecede düşüktü $(p<0,05)$. Serum fosfor, ALP, PTH ve 25-OHD düzeyleri açısından gruplar arasında anlamlı bir fark yoktu. Tüm hastaların başvuru yaşı ile boy SDS arasında negatif korelasyon ( $r=-0,622$ ve $p=0,001$ ), serum fosfor düzeyleri arasında negatif korelasyon ( $r=-0,512$ ve $p=0,005)$, kalsiyum düzeyleri arasında pozitif korelasyon ( $r=0,419$ ve $p=0,026)$, PTH düzeyleri arasında pozitif korelasyon ( $r=0,457$ ve $p=0,019)$ vardı. Serum kalsiyum düzeyi ile hem hastaların $(r=0,413$ ve $p=0,029)$ hem de annelerinin $(r=0,725$ ve $p=0,042) 25-O H D$ düzeyleri arasında pozitif korelasyon vardı. Çalışmaya dâhil edilen hastaların biyokimyasal özellikleri Tablo 2'de gösterilmiştir.

Hastaların annelerinin gebelik ve emzirme döneminde düzenli sağlık kontrollerinin yapılmadığı, yapılanların ise hiçbirinin önerilen D vitamini desteğini kullanmadığı öğrenildi. Sekiz hastanın annesi D vitamini eksikliği açısından tetkik edilmiş, tamamında eksiklik saptanmışt. Bir annede hafif, 2 annede orta, 5 annede ise ağır D vitamini eksikliği bulundu. Bir annede hipokalsemi

Tablo 3: Nütrisyonel riketsli olguların annelerinin biyokimyasal özellikleri

\begin{tabular}{lcc}
\hline Hasta anneleri (n=8) & $\begin{array}{c}\text { Ortanca } \\
\text { (alt-üst sınır) }\end{array}$ & $\begin{array}{c}\text { Normal } \\
\text { değerler }\end{array}$ \\
\hline Kalsiyum (mg/dL) & $8,8(6,5-9,5)$ & $8,5-10,5$ \\
Fosfor (mg/dL) & $3,6(3-5)$ & $2,5-4,5$ \\
Alkalen fosfataz (U/L) & $106(66-344)$ & $35-105$ \\
Parathormon (pg/mL) & $190(43-397)$ & $15-65$ \\
25-hidroksi vitamin D (ng/mL) & $4(3-12,2)$ & $30-100$ \\
\hline
\end{tabular}

Tablo 2: Nütrisyonel riketsli olguların biyokimyasal özellikleri*

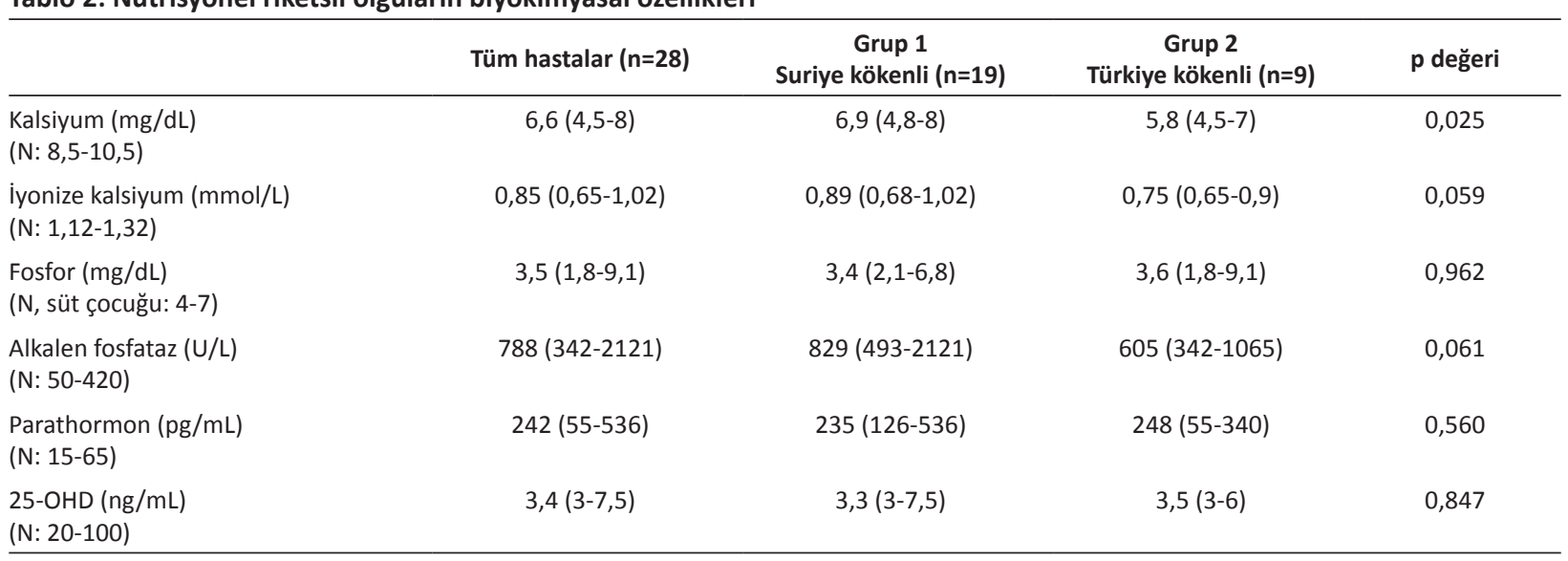

*Değerler ortanca (alt-üst sınır) olarak verilmiştir. 25-OHD: 25-hidroksi vitamin D 
saptandı (kalsiyum: 6,5 mg/dL) ve kalsiyum tedavisi başlandı. Tüm annelere tedavi dozunda (6000 IU/gün) D vitamini başlandı. Çalışmaya dâhil edilen hastaların annelerinin biyokimyasal özellikleri Tablo 3'de gösterilmiştir.

\section{TARTIŞMA}

Çalışmamızda kış ve ilkbahar aylarını kapsayan 5 aylık bir süreçte hastane yatışı gerektiren hipokalsemi nedeniyle izlenen ve nütrisyonel rikets tanısı alan süt çocukluğu dönemindeki olgularımızın verileri sunulmuştur. Hastalarımızın tamamında orta veya ağır düzeyde D vitamini eksikliği saptanmıştır. Hastaların yarıdan fazlası hiç D vitamini profilaksisi almamış, geri kalanlar ise düzensiz kullanmıştır. Son yıllarda yapılan çalışmalarda, ülkemizde uygulanan $D$ vitamini destek programına rağmen nütrisyonel rikets olgularının halen görülmekte olduğu ve çalışmamızda olduğu gibi bu olguların önemli bir kısmında D vitamininin kullanılmadığı veya düzensiz kullanıldığı bildirilmiştir (15). D vitamini kullanmama nedeni olarak ise ailelerin bu vitaminin önemini bilmemeleri ve ilaç kullanımına uyum göstermemeleri öne sürülmüştür. D vitaminin 400 IU/gün düzenli kullanımının riketsi önlemede etkin olduğu bilinmektedir (16).

İstanbul ilinde iki büyük eğitim ve araştrrma hastanesinde yapılan çalışmamızda hastaların üçte ikisi Suriye kökenli göçmen çocuklardır. Son yıllarda yapılan çalışmalarda çocuklarda D vitamini eksikliğinin yaygın olarak gözlendiği, özellikle de göçmenlerde bu oranın daha fazla olduğu bildirilmiştir (17-19). Ülkemizde 171 Suriye ve Iraklı göçmen çocuğun dahil edildiği bir çalışmada olguların \%40,9'unda tedavi gerektiren D vitamini eksikliği (<12 $\mathrm{ng} / \mathrm{ml}$ ) tespit edilmiştir. Bu çalışmada yaş ortalaması 10,1 $1 \pm 5,3$ yaş olup, özellikle kız çocuklarda ve 10 yaşın üzerindeki çocuklarda D vitamini seviyelerinin daha düşük olduğu gözlenmiştir (20). Göç eden sığınmacılar çeşitli sağlık sorunları açısından risk altında olan bir gruptur. Yapılan çalışmalarda sığınmacıların koruyucu sağlık hizmetlerinden faydalanma oranları oldukça düşüktür (21-23). Bir toplum sağlığı merkezinde sığınmacı ve mültecilere verilen birinci basamak sağlık hizmetlerinin değerlendirildiği bir çalışmada en sık başvuru nedeni enfeksiyon $(\% 58,2)$ olup, önleyici bakım için başvuranların oranı oldukça düşük saptanmıştır $(\% 10,1)(22)$. Çalışmamızda hastaların büyük çoğunluğunun Suriye uyruklu göçmenlerin oluşturması kötü yaşam koşulları, beslenme sorunları, dil problemleri, maddi sıkıntılar ve sağlık hizmetlerine erişim eksikliği nedeniyle olabilir.

Rikets büyümenin hızlı olduğu dönemlerde ortaya çıkan bir hastalık olup sıklığı süt çocukluğu ve adölesan döneminde artmaktadır. Çalışmamızda hastaların ortanca yaşı 8,8 ay olup yarısı hipokalsemik konvülsiyon nedeniyle başvurarak tanı almıştır. Olguların büyük çoğunluğunun yaşamın ilk 1 yılı içinde olması, tamamında $D$ vitamini eksikliği saptanması ve yarısının ciddi bir tablo olan konvülsiyon nedeniyle başvurması $D$ vitamini profilaksisinin önemini ortaya koymaktadır. Bir-24 ay arası süt çocuklarında afebril konvülsiyonların nedenlerinin araştırıldığı bir çalışmada, altta yatan neden $\% 25,6$ oranında riketse bağlı hipokalsemi olarak saptanmıştır (3). Hipokalsemik konvülsiyon geçiren 60 süt çocuğunun incelendiği bir çalışmada bebeklerin $\% 90$ 'ının, annelerinin ise yaklaşık \%85'inin vitamin D seviyesi
$<10 \mathrm{ng} / \mathrm{mL}$ saptanmıştır (24). Yaşamın ilk 3 ayında D vitamini eksikliği tanısı alan 42 süt çocuğunun incelendiği bir çalışmada olguların \%78,7'sinin hipokalsemik konvülsiyon nedeniyle başvurduğu bildirilmiştir (25). Bu çalışmada hastaların \%83'ünün D vitamini desteği almadan sadece anne sütü ile beslendiği, annelerin hiçbirinin gebeliği sırasında D vitamini desteği almadığı, tüm annelerin güneş ışığı maruziyetinin yetersiz ve $D$ vitamini düzeylerinin düşük olduğu görülmüştür. Maternal D vitamini yetersizliği açısından risk faktörleri düşük sosyoekonomik durum, dini/kültürel nedenlerle kapalı giyinme ve düşük eğitim düzeyi olup ülkemizde de önemli bir sorundur $(26,27)$. Göçmen Suriyeli annelerde bunlara ek olarak dil problemleri, koruyucu sağlık hizmetlerine ulaşamama ve adres değişiklikleri nedeniyle takiplerin devam ettirilememesi riski artırmaktadır. Maternal D vitamini yetersizliği erken bebeklik döneminde riketsle sonuçlanmaktadır (28). Çalışmamızda annelerin gebelik ve emzirme döneminde düzenli sağ ıık kontrollerinin yapılmadığı, D vitamini desteği kullanmadığı öğrenilmiş ve tüm annelerde $D$ vitamini eksikliği saptanmıştır.

Hastalarımızın konvülsiyon sonrası ikinci sıklıkta tanı alma yolu rastlantısal olarak hipokalsemi saptanmasıdır. Bu hastaların büyük çoğunluğu enfeksiyon nedeniyle acil servise başvuran hastalardır. Nütrisyonel riketsli 946 hastanın incelendiği bir çalışmada 0-6 yaş arasındaki hastalarda en sık başvuru sebebi enfeksiyonlardır (9). Çalışmamızda en sık başvuru nedeninin konvulsiyon olması, hastaların yaş ortalamasının küçük olması, çalışmaya yalnızca yatış endikasyonu bulunan hipokalsemi hastalarının dahil edilmesi ve ayaktan tedavisi düzenlenen nütrisyonel rikets olgularının dahil edilmemesi olabilir. Ülkemizde nütrisyonel rikets nedeniyle başvuruların yıl boyunca dağılımının da incelendiği aynı çalışmada olgular Aralık-Mayıs ayları arasında bir yoğunluk göstermiştir (9). Göçmen ve sığınmacı Suriyeli çocuklarda D vitamini düzeyleri incelendiğinde EkimNisan aylarında vitamin düzeyleri daha düşük bulunmuştur (29). Çalışmamız yıl içinde benzer mevsimsel aralıkta tamamlanmış ve bu dönemde yoğun hasta başvurusu dikkat çekmiştir.

Çalışmamızda hipokalsemi yanında nütrisyonel riketste beklenen biyokimyasal parametreler olan 25-OHD düşüklüğü, ALP ve PTH yüksekliği hastalarda saptanmıştr. Nütrisyonel riketste hem tarama hem tanı hem de tedaviye yanıtın izlenmesinde ALP güvenilir ve maliyeti düşük bir biyokimyasal belirteçtir (30). PTH düzeyi normal aralıkta olan tek hastamız ağır hipokalsemi ve ağır D vitamini eksikliği ile başvurmuş, izleminde $D$ vitamini ve kalsiyum tedavisi ile kliniği ve laboratuvar değerleri tamamen düzelmiş ve nütrisyonel rikets tanısı doğrulanmıştır. Erken bebeklik döneminde $D$ vitamini yetersizliğinin özelliklerinin araştırıldığı bir çalışmada bütün bebeklerin serum kalsiyum düzeyleri düşük bulunmasına karşın sekonder hiperparatiroidi vakaların \%68'inde saptanmıştı. Hiperparatiroidinin beklenen düzeyde olmaması erken bebeklik döneminde PTH ve diğer serum kalsiyum düzenleyici faktörlerin immatüritesine bağlanmıştr (28). Bu hastalar fonksiyonel hipoparatiroidizme bağlı olarak şiddetli hipokalsemi ile başvurmaktadır (31).

Diğer yandan nütrisyonel rikets vakalarında hipokalsemi ve sekonder hiperparatiroidi yanında görülebilen hiperfosfatemi 
birlikteliğinin PTH direncine bağlı olabileceği ileri sürülmüştür (28). Ayrıca yenidoğan döneminde PTH cevabının immatür ve renal fosfor atılımının düşük olduğu, bu nedenle de konjenital rikets vakalarında hiperfosfateminin beklenen bir bulgu olduğu bildirilmektedir (32). Orbak ve ark. (28) erken dönem rikets vakalarında sekonder hiperparatiroidiye rağmen normal ve yüksek fosfor değerlerinin sık görülebileceğini ve bu bulgu nedeniyle vakalarda D vitamini yetersizliği tanısından vazgeçilmemesi gerektiğini vurgulamıştır. Çalışmamızda literatürle uyumlu olarak vakalarımızın \%40'ında fosfor düzeyleri normal veya yüksek saptanmıştır. Hiperfosfatemi saptanan olgumuz 1,5 aylıktır.

Sonuç olarak, nütrisyonel rikets ülkemizde halen önemli ve önlenebilir bir halk sağlığı sorunu olmaya devam etmektedir. D vitamini eksikliği özellikle küçük süt çocuklarında kış-ilkbahar aylarında hipokalsemik konvülsiyon nedeniyle hastane başvurularına yol açabilmektedir. Özellikle yüksek risk altında olan göçmen Suriyeli süt çocuklarında D vitamini destek programına uyumun artırılması nütrisyonel riketsin önlenmesi açısından önemlidir. Göçmen ailelere, birinci basamak sağlık kuruluşlarında D vitamini kullanımının ve tedaviye uyumun önemi anlatılmalı, gerekli durumlarda tercüman yardımı alınması sağlanmalıdır. Ülkemizde çok fazla sayıda göçmen sığınmacı yaşadığı göz önünde bulundurularak, sığınmacıların koruyucu sağlık hizmetlerinden yararlanma durumlarının artırılması hedeflenmelidir. Ayrıca annelerin emzirme döneminde $D$ vitamin desteğine devam edip etmedikleri sorgulanmalı ve kullanmaları desteklenmelidir.

Etik Komite Onayı: Bu çalışma için etik komite onayı Bağcılar Eğitim ve Araştırma Hastanesi Klinik Araştırmalar Etik Kurulu'ndan alınmıştır. (No: 2018.11.2.03.100.r1.111)

Bilgilendirilmiş Onam: Retrospektif bir çalışma olduğundan bilgilendirilmiş onam alınmamıştır.

Hakem Değerlendirmesi: Dış bağımsız.

Yazar Katkıları: Çalışma Konsepti/Tasarım- M.Y., S.K.; Veri ToplamaM.Y., S.K.; Veri Analizi/Yorumlama- M.Y.; Yazı Taslağı- M.Y., S.K.; İçeriğin Eleştirel İncelemesi- S.K.; Son Onay ve Sorumluluk- M.Y., S.K.; Malzeme ve Teknik Destek- M.Y., S.K.; Süpervizyon- M.Y., S.K.

Çıkar Çatışması: Yazarlar çıkar çatışması beyan etmemişlerdir.

Finansal Destek: Yazarlar finansal destek beyan etmemişlerdir.

Ethics Committee Approval: This study was approved by the Bağcılar Training and Research Hospital Clinical Research Ethics Committee. (No: 2018.11.2.03.100.r1.111)

Informed Consent: Informed consent was not received due to the retrospective nature of the study.

Peer Review: Externally peer-reviewed.

Author Contributions: Conception/Design of Study- M.Y., S.K; Data Acquisition- M.Y., S.K.; Data Analysis/Interpretation-M.Y.; Drafting Manuscript- M.Y., S.K.; Critical Revision of Manuscript- S.K.; Final
Approval and Accountability- M.Y., S.K.; Technical or Material SupportM.Y., S.K.; Supervision- M.Y., S.K.

Conflict of Interest: Authors declared no conflict of interest.

Financial Disclosure: Authors declared no financial support.

\section{KAYNAKLAR/REFERENCES}

1. Joiner TA, Foster C, Shope T. The many faces of vitamin D deficiency rickets. Pediatr Rev 2000;21:296- 302.

2. Cesur Y. Nutrisyonel rikets. Turkiye Klinikleri J Pediatr Sci 2012;8:3341.

3. Cetinkaya F, Sennaroglu E, Comu S. Etiologies of seizures in young children admitted to an inner city hospital in a developing country. Pediatr Emerg Care 2008;24:761-3.

4. Munns CF, Shaw N, Kiely M, Specker BL, Thacher TD, Ozono K, et al. Global Consensus Recommendations on Prevention and Management of Nutritional Rickets. J Clin Endocrinol Metab 2016;101:394-415.

5. Han P, Trinidad BJ, Shi J. Hypocalcemia induced seizure: demystifying the calcium paradox. ASN Neuro 2015; Mar 24;7(2):1759091415578050. doi: 10.1177/1759091415578050. PMID: 25810356; PMCID: PMC4374060.

6. Ahmed I, Atiq M, Iqbal J, Khursid M, Whittaker P. Vitamin $D$ deficiency rickets in breast-fed infants presenting with hypocalcemic seizures. Acta Paediatr 1995;84:941-942.

7. Özkan B, Büyükavcı M, Aksoy H, Tan H, Akdağ R. Erzurum'da 0-3 yaş grubu çocuklarda nütrisyonel rikets sıklığı. Çocuk Sağlığı ve Hastalıkları Dergisi 1999;42:389-96.

8. Ozkan B, Doneray H, Karacan M, Vançelik S, Yıldırım ZK, Ozkan A, et al. Prevalence of vitamin $D$ deficiency rickets in the eastern part of Turkey. Eur J Pediatr 2009;168:95-100.

9. Cesur $Y$, Doğan M, Ariyuca S, Basaranoglu M, Bektas MS, Peker $\mathrm{E}$, et al. Evaluation of children with nutritional rickets. J Pediatr Endocrinol Metab 2011;24:35-43.

10. Thacher TD, Fischer PR, Tebben PJ, Singh RJ, Cha SS, Maxson JA, et al. Increasing incidence of nutritional rickets: A populationbased study in Olmsted County, Minnesota, USA: In: Mayo Clinic Proceedings. Elsevier 2013;176-83.

11. Hatun S, Bereket A, Ozkan B, Coskun T, Kose R, Calıkoğlu AS. Free vitamin $D$ supplementation for every infant in Turkey. Arch Dis Child 2007;92:373-4.

12. Lane G, Farag M, White J, Nisbet C, Vatanparast H. Chronic health disparities among refugee and immigrant children in Canada. Appl Physiol Nutr Metab 2018;43(10):1043-58.

13. Pavlopoulou ID, Tanaka M, Dikalioti S, Samoli E, Nisianakis P, Boleti $\mathrm{OD}$, et al. Clinical and laboratory evaluation of new immigrant and refugee children arriving in Greece. BMC pediatr 2017;17(1):132.

14. T.C. İçişleri Bakanlığı Göç İdaresi Genel Müdürlüğü. Geçici koruma kapsamındaki Suriyeliler. Erişim: https://www.goc.gov.tr/gecicikoruma5638 (05.06.2020 itibariyle)

15. Küçükali G, Kurnaz E, Erdeve Ş, Aycan Z. Ülkemizde D vitamini profilaksisine rağmen devam eden bir problem: Nutrisyonel rikets. Türkiye Çocuk Hastalıkları Dergisi 2017;11(2):102-98.

16. Mutlu GY, Kusdal Y, Ozsu E, Cizmecioglu FM, Hatun S. Prevention of Vitamin D deficiency in infancy: Daily $400 \mathrm{IU}$ vitamin $D$ is sufficient. Int J Pediatr Endocrinol 2011;2011:4. 
17. Lips $\mathrm{P}$, de Jongh RT. Vitamin D deficiency in immigrants. Bone Rep 2018;9:37-41.

18. Pedersen P, Michaelsen KF, Molgaard C. Children with nutritional rickets referred to hospitals in Copenhagen during a 10-year period. Acta paediatr 2003;92(1):87-90.

19. Hintzpeter B, Scheidt-Nave C, Muller MJ, Schenk L, Mensink GB. Higher prevalence of vitamin D deficiency is associated with immigrant background among children and adolescents in Germany. J Nutr 2008;138(8):1482-90.

20. Sarı E. Suriye ve Iraklı göçmen çocuklarda $D$ vitamini eksikliği. Güncel Pediatri 2020;18(1):113-104.

21. Zencir M, Davas A. Suriyeli Sığınmacılar ve Sağılı Hizmetleri Raporu. Türk Tabipler Birliği Web sitesi. Erişim: https://www.ttb.org.tr/ kutuphane/ siginmacirpr.pdf. Erişim tarihi 10 Ağustos 2018.

22. Aygün O, Gökdemir Ö, Bulut Ü, Yaprak S, Güldal D. Bir toplum sağlığı merkezi örneğinde sığınmacı ve mültecilere verilen birinci basamak sağlık hizmetlerinin değerlendirilmesi. TJFM\&PC 2016;10:6-12.

23. AFAD. Republic of Turkey Prime Ministry Disaster and Emergency Management Presidency. Syrian Refugees in Turkey, 2013: Field Survey Results. Ankara,Turkey:AFAD;2013.

24. Mehrotra P, Marwaha RK, Aneja S, Seth A, Singla BM, Ashraf G, et al. Hypovitaminosis $d$ and hypocalcemic seizures in infancy. Indian Pediatr 2010;47:581-6.
25. Hatun S, Ozkan B, Orbak Z, Doneray H, Cizmecioglu F, Toprak D, et al. Vitamin D deficiency in early infancy. J Nutr 2005;135: 279- 82.

26. Pehlivan I, Hatun Ş, Aydoğan M, Babaoğlu K, Türker G, Gökalp AS. Maternal serum vitamin D levels in the third trimester of pregnancy. Turk J Med Sci 2002;32:237-241.

27. Andıran N, Yordam N, Ozön A. The risk factors for vitamin D deficiency in breast-fed newborns and their mothers. Nutrition 2002;18:47-50.

28. Orbak Z, Hatun Ş, Özkan B, Döneray H, Çizmecioğlu F, Toprak D. Erken bebeklik döneminde $D$ vitamini yetersizliğinin özellikleri. Çocuk Sağlığı ve Hastalıkları Dergisi 2005;48:8-13.

29. Orbatu D, Alaygut $D$, Baltali O. Evaluation of levels of vitamin $D$ in immigrant and refugee children: single center experience. MOJ Women's Health 2019;8(5):299-301.

30. Al-Atawi MS, Al-Alwan IA, Al-Mutair AN, Tamim HM, Al-Jurayyan NA. Epidemiology of nutritional rickets in children. Saudi J Kidney Dis Transpl 2009;20:260-5.

31. Bonnici F. Functional hypoparathyroidism in infantile hypocalcemic stage I vitamin D deficiency rickets. Afr Med J 1978;54:611-612.

32. Ramavat LG. Vitamin D deficiency rickets at birth in Kuwait. Indian J Pediatr 1999;66:37-43. 